\title{
On the variability of the temporal pattern of vibrational calling signals in leafhoppers (Homoptera: Cicadellidae)
}

\section{Об изменчивости ампиитудно-временно́го рисунка призывных сигналов цикадок (Homoptera: Cicadellidae)}

\author{
D.Yu. Tishechkin \\ A.Ю. Тишечкин
}

Department of Entomology, Faculty of Biology, M.V. Lomonosov Moscow State University, Vorobyevy Gory, Moscow 119991, Russia. E-mail: macropsis@yandex.ru

Кафедра энтомологии Биологического факультета Московского государственного университета им. М.В. Ломоносова, Воробьёвы Горы, Москва 119991, Россия.

KEY WORDS: leafhoppers, Homoptera, Cicadellidae, vibrational signals, calling signals, temporal pattern, variability.

КЛЮЧЕВЫЕ СЛОВА: цикадки, Ноmoptera, Cicadellidae, вибрационные сигналы, призывные сигналы, амплитудно-временно́й рисунок, изменчивость.

ABSTRACT. Different kinds of variability of calling signals in Cicadellidae are described. In leafhoppers, not only the duration and repetition period of the elements of the signals, but also the general scheme of their temporal pattern can vary to a great extent. The songs of certain species include prolonged and elaborate additional components, which are not the necessary parts of the song and sometimes are reduced partially or fully. Consequently, the presence or absence of such components is not a species-specific character, and vice versa, the presence of identical components even in the signals differing distinctly from each other suggests their conspecificity.

РЕЗЮМЕ. Рассмотрены различные типы изменчивости призывных сигналов Cicadellidae. Показано, что изменчивости могут быть подвержены не только длительность и период повторения элементов сигнала, но и общий план амплитудно-временно́го рисунка. У многих видов в сигнале могут присутствовать продолжительные и сложные по структуре факультативные фрагменты, которые не являются его обязательной частью и могут быть отчасти или полностью редуцированы. В связи с этим, наличие или отсутствие таких компонентов не является видовым признаком; в то же время, присутствие идентичных компонентов даже в сильно различающихся по структуре сигналах может свидетельствовать об их конспецифичности.

\section{Introduction}

In many groups of insects acoustic communication signals (songs) play the main role in recognition of a conspecific mate. As a rule, male ready for copulation produce calling signals. Receptive conspecific female either moves towards the male using his song as a guide or produce reply signals. In the latter case female remains stationary and the male approaches it. In small Auchenorrhyncha, females normally sing only in reply to calling songs of conspecific males. Retranslation of heterospecific calling signals never induces their reply reaction [Ichikawa et al., 1975; Ichikawa, 1976; Inoue, 1982]. As a result, differences in the signal structure provide the main barrier of reproductive isolation between closely related species. For this reason comparative analysis of calling signal patterns appears to be particularly promising in taxonomy on species level.

In most cases the temporal pattern of calling signals is used as a taxonomic character for discrimination between closely related species or for elucidation of status of dubious forms of the species rank. The variability of this character usually has been neglected thus far, however. As a rule, the only oscillogram or several oscillograms of the same signal at different speeds are provided as some primary standard of the song of the species under consideration [e.g. Claridge \& Nixon, 1986]. Occasionally, the data on quantitative variability, i.e. on the duration and repetition period of the signal components are also given [den Bieman, 1986; Gillham \& De Vrijer, 1995; Percy et al., 2008]. Only in the comprehensive work on the variability in calling signals of the planthopper Javesella pellucida (Fabricius, 1794) (Homoptera, Delphacidae) the substrate-related changes of the shape of pulses and syllables are concerned with [De Vrijer, 1984].

Quantitative variability of signal structure in small Auchenorrhyncha displays the same general rules as were described in our previous papers for grasshoppers of the subfamily Gomphocerinae (Orthoptera, Acrid- 
idae) [Tishechkin, 2009; Tishechkin \& Bukhvalova, 2010]. In addition, in many species of Auchenorrhyncha the general pattern of calling song sometimes is so much variable that oscillograms of different signals of the same species look quite unlike one another. In our taxonomic works we have only provided a sufficient number of oscillograms to illustrate such variability without going into details of this matter [e.g. Tishechkin, 2000a, b, 2002]. In the present paper different kinds of variability of the temporal pattern of calling signals in leafhoppers (Homoptera, Cicadellidae) are discussed more comprehensively.

\section{Material and methods}

Vibrational signals were registered by means of piezo-electric crystal gramophone cartridge connected to the microphone input of cassette recorder "Elektronika-302-1" or minidisk recorder Sony Walkman (mod-

Table. Data for recordings of calling signals of the studied species of Cicadellidae. Таблица. Данные о записях призывных сигналов изученных видов Cicadellidae.

\begin{tabular}{|c|c|c|}
\hline Species & Locality & $\begin{array}{l}\text { Air temperature } \\
\text { during recording, }\end{array}$ \\
\hline Subfamily Idiocerinae & & \\
\hline Rhytidodus tenebricans & Kyrgyzstan, W Tien-Shan Mts., Chatkal'skiy Ridge, Sary- & $20-23$ \\
\hline $\begin{array}{l}\text { Dubovsky, } 1966 \\
\text { Subfamily Macropsinae }\end{array}$ & Chelekskiy Nature Reserve, env. Arkyt vill. & $20-20$ \\
\hline Hephathus nanus & Lower Volga Region, East of Saratov Area, $15 \mathrm{~km}$ NE of Ozinki Town. & 33 \\
\hline $\begin{array}{l}\text { (Herrich-Sch } \llbracket \text { ffer, } 1835) \\
\text { Subfamily Iassinae }\end{array}$ & South Urals, Guberlya River 25 km W of Orsk. & $26-28$ \\
\hline $\begin{array}{l}\text { Iassus lateralis (Matsumura, } \\
\text { 1905) }\end{array}$ & $\begin{array}{l}\text { Lower Volga Region, Saratov Area, Krasnokutskiy District, env. } \\
\text { Dyakovka vill. }\end{array}$ & 24 \\
\hline Subfamily Drabescinae & & \\
\hline $\begin{array}{l}\text { Drabescus vilbastei Zhang, } \\
\text { Webb, } 1996\end{array}$ & $\begin{array}{l}\text { Southern Maritime Province, W shore of Khanka Lake, } 10 \mathrm{~km} \mathrm{~S} \\
\text { of Turiy Rog. }\end{array}$ & 23 \\
\hline $\begin{array}{l}\text { Athysanopsis salicis } \\
\text { Matsumura } 1905\end{array}$ & D & $22-23$ \\
\hline $\begin{array}{l}\text { Matsumura, } 1905 \\
\text { Subfamily Deltocephalinae }\end{array}$ & & \\
\hline Tribe Deltocephalini & & \\
\hline $\begin{array}{l}\text { Alobaldia tobae } \\
\text { (Matsumura, 1901) }\end{array}$ & -------"------- & $24-26$ \\
\hline Tribe Paralimnini & & \\
\hline $\begin{array}{l}\text { Paramesus major Haupt, } \\
1927 \\
\text { Tribe Dorycephalini }\end{array}$ & $\begin{array}{l}\text { Lower Volga Region, East of Saratov Area, env. Ozinki Town, } \\
\text { Chalykla River. }\end{array}$ & $23-24$ \\
\hline $\begin{array}{l}\text { Dorycephalus baeri } \\
\text { Kouchakewitch, } 1866\end{array}$ & $\begin{array}{l}\text { Lower Volga Region, North of Saratov Area, env. Khvalynsk } \\
\text { Town, chalk hills near Ulvanino Village. }\end{array}$ & $27-28$ \\
\hline $\begin{array}{l}\text { D. hunnorum Emelyanov, } \\
1964\end{array}$ & $\begin{array}{l}\text { E Siberia, Buryatia, Selenga River } 5 \mathrm{~km} \text { north of Novoselenginsk } \\
\text { Town. }\end{array}$ & $25-26$ \\
\hline$\underline{\text { Tribe Cicadulini }}$ & & \\
\hline $\begin{array}{l}\text { Cicadula frontalis } \\
\text { mesasiatica Dubovsky } 1966\end{array}$ & Kyrgyzstan, W Tien-Shan Mts., Chatkal'skiy Ridge, Sary- & $23-24$ \\
\hline $\begin{array}{c}\text { Tribe Athysanini (incl. } \\
\underline{\text { Platymetopiini) }}\end{array}$ & Chelekskiy Nature Reserve, $\mathrm{N}$ shore of Sary-Chelek Lake. & \\
\hline $\begin{array}{l}\text { Handianus fartilis Mityaev, } \\
1975\end{array}$ & $\begin{array}{l}\text { Lower Volga Region, East of Saratov Area, } 10 \mathrm{~km} \mathrm{E} \mathrm{of} \mathrm{Ozinki} \\
\text { Town towards Ural'sk. }\end{array}$ & $26-27$ \\
\hline \multirow[t]{2}{*}{$\begin{array}{l}\text { Platymetopius koreanus } \\
\text { Matsumura, } 1915\end{array}$} & $\begin{array}{l}\text { E Siberia, Buryatia, Temnik River } 4-5 \text { km north of Selenduma } \\
\text { Town. }\end{array}$ & $28-29$ \\
\hline & $\begin{array}{l}\text { Southern Maritime Province, W shore of Khanka Lake, } 10 \mathrm{~km} \mathrm{~S} \\
\text { of Turiy Rog. }\end{array}$ & $24-25$ \\
\hline $\begin{array}{l}\text { Orientus ishidae } \\
\text { (Matsumura, 1902) }\end{array}$ & 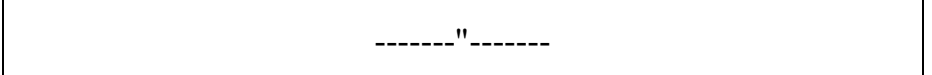 & $24-28$ \\
\hline $\begin{array}{l}\text { Allygidius mayri } \\
\text { (Kirschbaum, 1868) }\end{array}$ & $\begin{array}{l}\text { Lower Volga Region, Saratov Area, Krasnokutskiy District, env. } \\
\text { Dyakovka vill. }\end{array}$ & $27-28$ \\
\hline
\end{tabular}


els MZ-NH900 or MZ-RH910) via the custom-made matching amplifier. Recordings were made under field conditions in a tent immediately after collecting the insects.

For illustrations we have mainly selected the species from poorly studied groups, such as Idiocerinae, Drabescinae, Iassinae, and certain tribes of Deltocephalinae (Dorycephalini and Deltocephalini s.str.). Thus, we used the opportunity to provide new data on signal structure in these taxa. Notice that we do not treat Platymetopiini as a separate tribe, but include it into Athysanini (Delto- cephalinae) following Emelyanov [1999]. However, three of four species from this group (Platymetopius koreanus Matsumura, 1915, Allygidius mayri (Kirschbaum, 1868) and Orientus ishidae (Matsumura, 1902)) belong rather to Platymetopiini than to Athysanini s. str. [Hamilton, 1975; Emelyanov, 1999].

Data on collecting sites and temperature during recording for the signals presented on oscillograms are given in the Table. All specimens investigated are deposited in the collection of the Zoological Museum of M.V. Lomonosov Moscow State University.

1

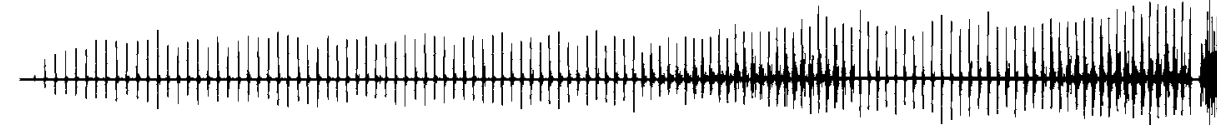

2
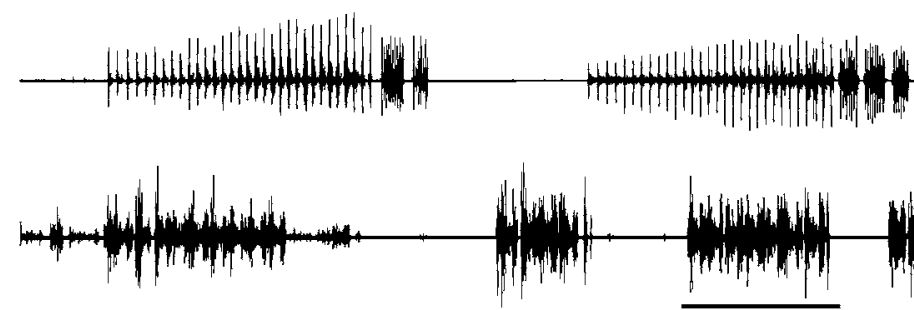

$2 \mathrm{~s}$

4

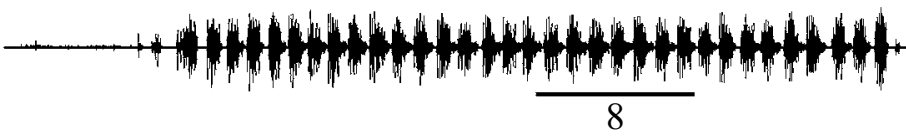
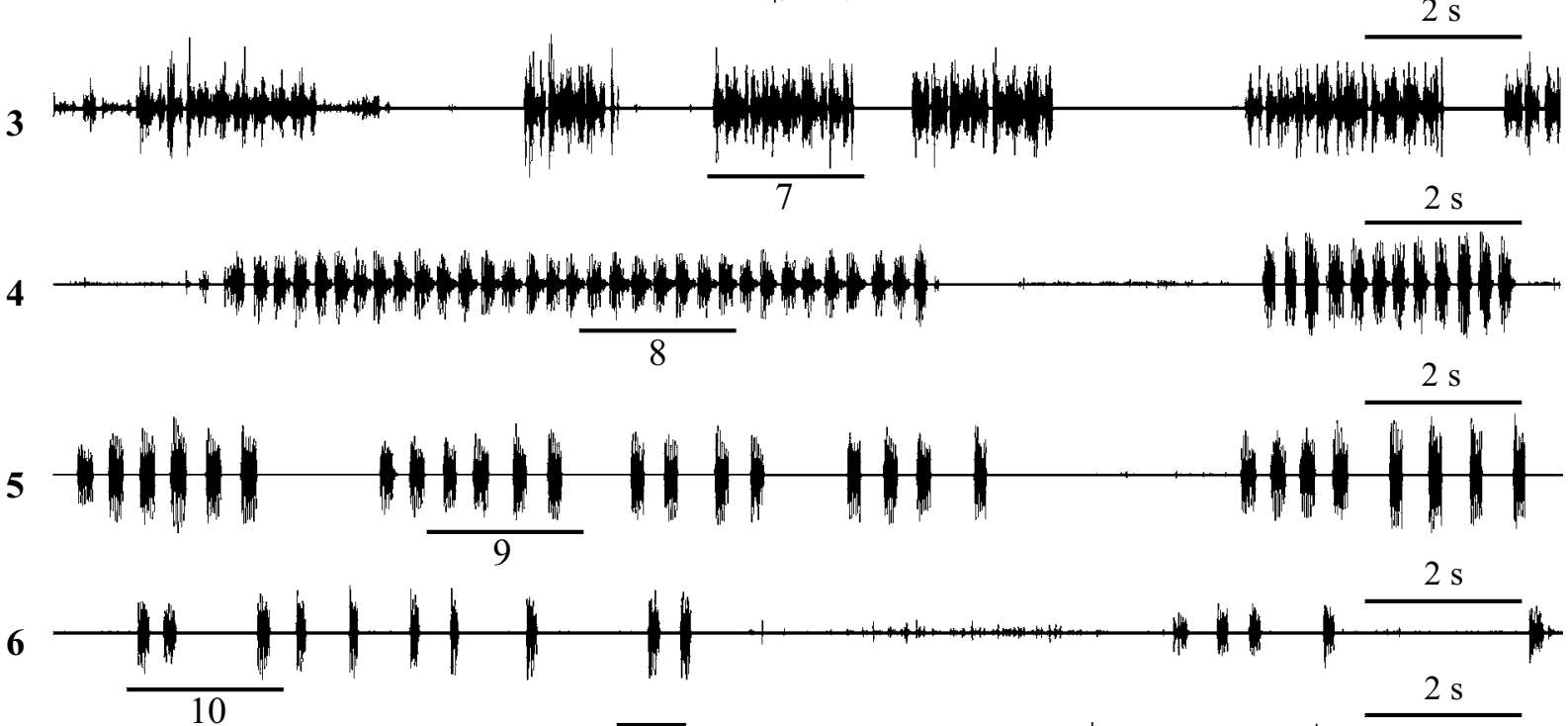

7
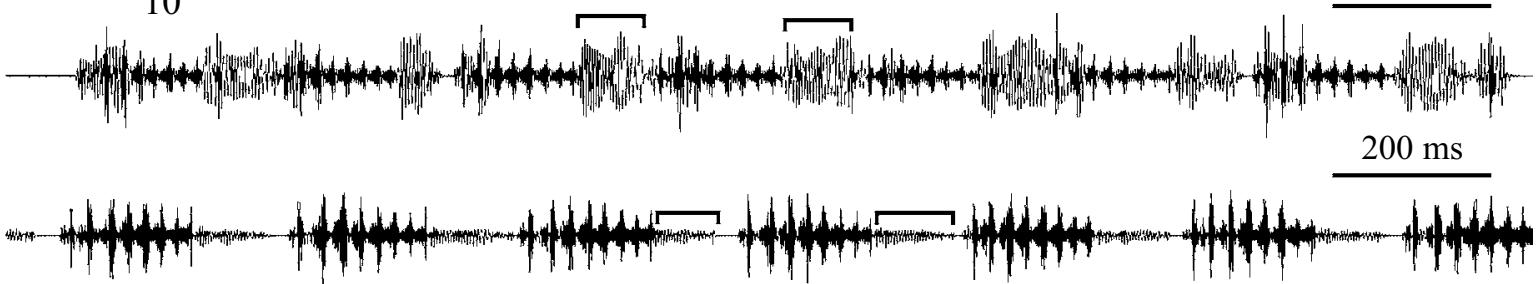

9

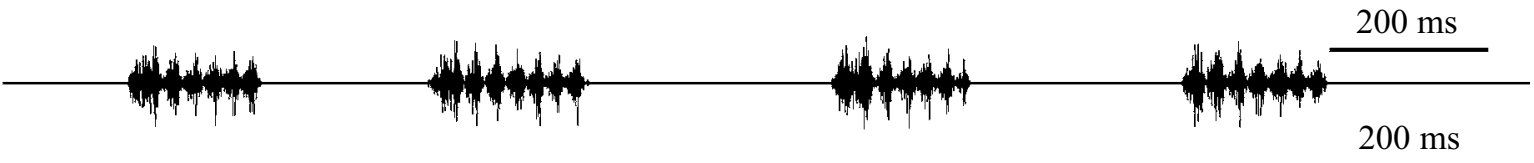

10
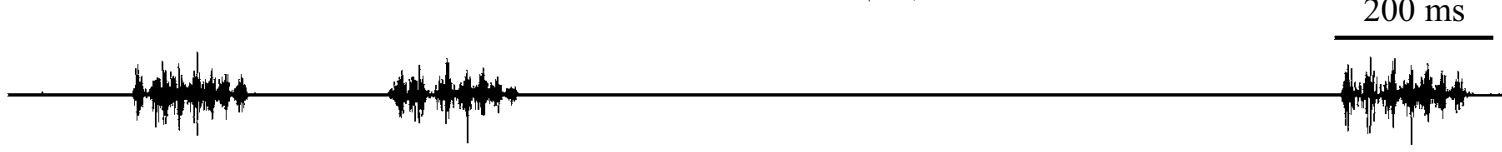

$200 \mathrm{~ms}$

Figs. 1-10. Oscillograms of calling signals of Cicadellidae: $1-2$ - Handianus fartilis; 4-10 - Hephathus nanus; 3-4 and 7-8 - the male from Saratov Area; 5-6 and 9-10 - males from South Urals. Faster oscillograms of the parts of signals indicated as "7-10" are given under the same numbers.

Рис. 1-10. Осциллограммы призывных сигналов Cicadellidae: 1-2 - Handianus fartilis; 4-10 - Hephathus nanus; 3-4 и 7-8 самец из Саратовской обл.; 5-6 и 9-10 - самцы с Южного Урала. Фрагменты сигналов, помеченные цифрами “7-10”, представлены при большей скорости развёртки на осциллограммах под соответствующими номерами. 


\section{Results and discussion}

In certain cases the variability of signal structure is restricted to the changes of the quantitative parameters, i.e. phrase duration or syllable repetition period. Quite often the phrases in the specimens from the same locality can differ from each other in duration by a factor of three and more. However, in spite of such differences identical elements on different oscillograms are always distinctly visible. An example is provided by the calling signals of Handianus fartilis Mitjaev, 1975 (Figs 1-2).

If the syllable repetition period increases much, the signal can split into separate fragments following each other with irregular intervals. For example, in Hephathus nanus (Herrich-Schäffer, 1835) the phrase is composed of syllables including succession of pulses and the variable low-frequency component each (indicated by square brackets on Figs 7-8). This component quite often is almost reduced and the gaps between syllables become more distinct (Fig. 8). If the duration of gaps increases, the phrase splits into separate syllables each consisting of succession of pulses only (Fig. 9); occasionally, syllables follow each other with prolonged irregular intervals (Fig. 10). The general view of a signal changes drastically in the course of such transformations (Figs 3-6), but comparison of oscillograms at high speed (Figs. 7-10) allows revealing similar components in the songs looking (and sounding for human ear) quite unlike one another.

The shape of syllables can vary to some extant even within the same signal. Apparently, this is a result of changes in the working of sound apparatus, i.e. timbals. The distortion of waves during transmission via the substrate can hardly cause the differences between syllables in this case, because the insect usually remains stationary during singing and does not change its position in relation to vibrotransducer. By way of example, in Drabescus vilbastei Zhang, Webb, 1996 the lowamplitude initial part in different syllables can be well developed or, on the contrary, almost entirely absent within the same calling song (Figs 11-15).

Similar differences not within, but between the signals, as for instance, in the songs of Platymetopius undatus Matsumura, 1915 presented on Figs 16-20, partly can also result from the differences in frequency characteristics of a substrate on which the insect sing. As it was shown by Michelsen and co-authors [Michelsen et al., 1982], every solid substrate is a complex frequency filter for insect vibrational signals. Since the plants have very complicated geometry and distribution of a mass over the length, every part of every stem or twig has its own filtering properties. Thus, the shape of the waves depends much on physical properties of a particular part of a plant and consequently on relative position of singing insect and vibrotransducer. In the special case that the parts of syllable differ form each other in frequency spectra their attenuation also will be different. For this reason the shape of syllable or, more precisely, amplitude relation of its different parts can vary with the change of position of the insect on the stem.
Example is provided by recording of signals of several males of Cicadula frontalis mesasiatica Dubovsky, 1966 singing in different points on the same plant (Figs 21-24). General pattern of syllables in all individuals is similar, but the relative amplitudes of the initial lowfrequency pulse (indicated by arrows on Figs 22-24) and the succeeding part vary considerably.

Some further examples are given on Figs 25-27 (Iassus lateralis (Matsumura, 1905)) and 28-31 (Rhytidodus tenebricans Dubovsky, 1966). It should be noted, that in the last species the signal consists of two parts, the first having the lower main frequency than the second (Figs 28-29). The male vibrates by abdomen distinctly when producing the signal; it can be assumed that the low-frequency part is generated by means of tremulation, i.e. vibration of the abdomen without the contact with the substrate. Anyway, attenuation of two parts of signal sometimes is different resulting in considerable decrease of the amplitude of the second one (Figs 30-31).

In certain species the songs include additional components, which are not the necessary parts of the song and can be either reduced to some extent or entirely absent. For instance, in the representatives of the genus Dorycephalus Kouchakewitch, 1866 the main part of the calling signal is a succession of rather short uniform syllables (Figs 36-38 and 45). Occasionally the signal consists of such syllables only (Figs. 33-34 and 41). In other cases prolonged train of short clicks and several syllables of somewhat different shape precede the main part (Figs. 32, 35 and 39-40, 42-43). Investigation of a sufficient number of signals allows revealing all the transition variants between the extreme types of their structure (Figs 39-41), but in certain cases oscillograms of conspecific signals differ much from each other (e.g. Figs 32 and 34 or Figs 39 and 41).

In the signals of Orientus ishidae (Matsumura, 1902) certain syllables have more complicated pattern due to the larger number of pulses in the initial part and the presence of the additional low-amplitude monotonous component (Figs 46, 48). On the other hand, sometimes the male produce only simple short syllables (Figs 47, 49). Similar situation was observed in Allygidius mayri (Kirschbaum, 1868): quite often additional part presents in the beginning of the syllables (Figs 50, 52 and 51, 53). It should be emphasized that for both species the calling signals produced by the single male during a period of about half an hour are presented on oscillograms.

Quite often additional components have more elaborate temporal structure than the main one. Calling signal of Athysanopsis salicis Matsumura, 1905 provides an example. Its obligatory part is a prolonged monotonous fragment sounding like buzz for human ear (Figs. 54, 56). Additional part has much more complex pattern and consists of syllables slightly increasing in duration towards the end of the song (Figs 55, 57-58).

Full signal of Paramesus major Haupt, 1927 is a phrase (Fig. 59) composed of prolonged succession of pulses with rather variable shape (Fig. 61) and one or two syllables (Fig. 62). Occasionally male produce only final syllables (Figs 60, 63); therefore, the main compo- 
nent of the song has less complex pattern and lower duration than the additional one.

In the signals of certain species combination of different kinds of variability is observed. For instance, the full song of Alobaldia tobae (Matsumura, 1901) (Fig. 64) consists of prolonged succession of syllables (Fig. 67) followed by several discrete fragments (Fig. 68). As in the case of $P$. major, the succession of syllables sometimes is absent and the signal reduces to the train of discrete fragments; in this case their number usually is higher than in the full song (Figs 65-66). The pattern of the fragments is also variable. If the fragment consists of several elements differing distinctly from each other it can be classified as a syllable (Fig. 69), the fragments having simpler structure (Figs 70-71) can be assigned to the category of pulses.

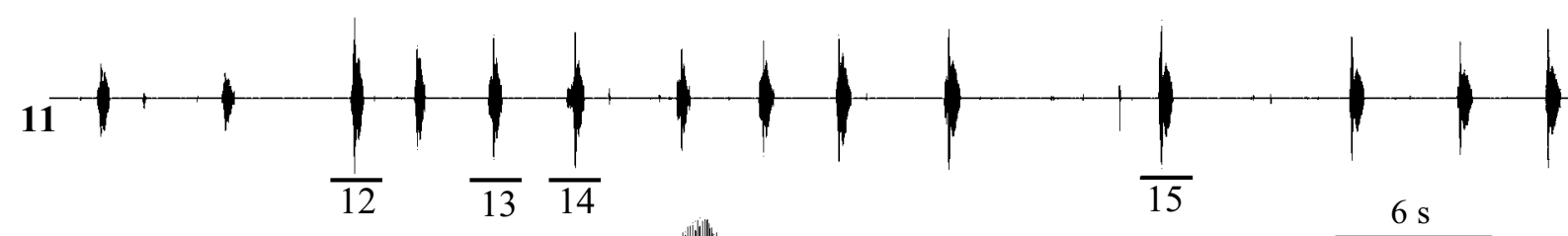

12
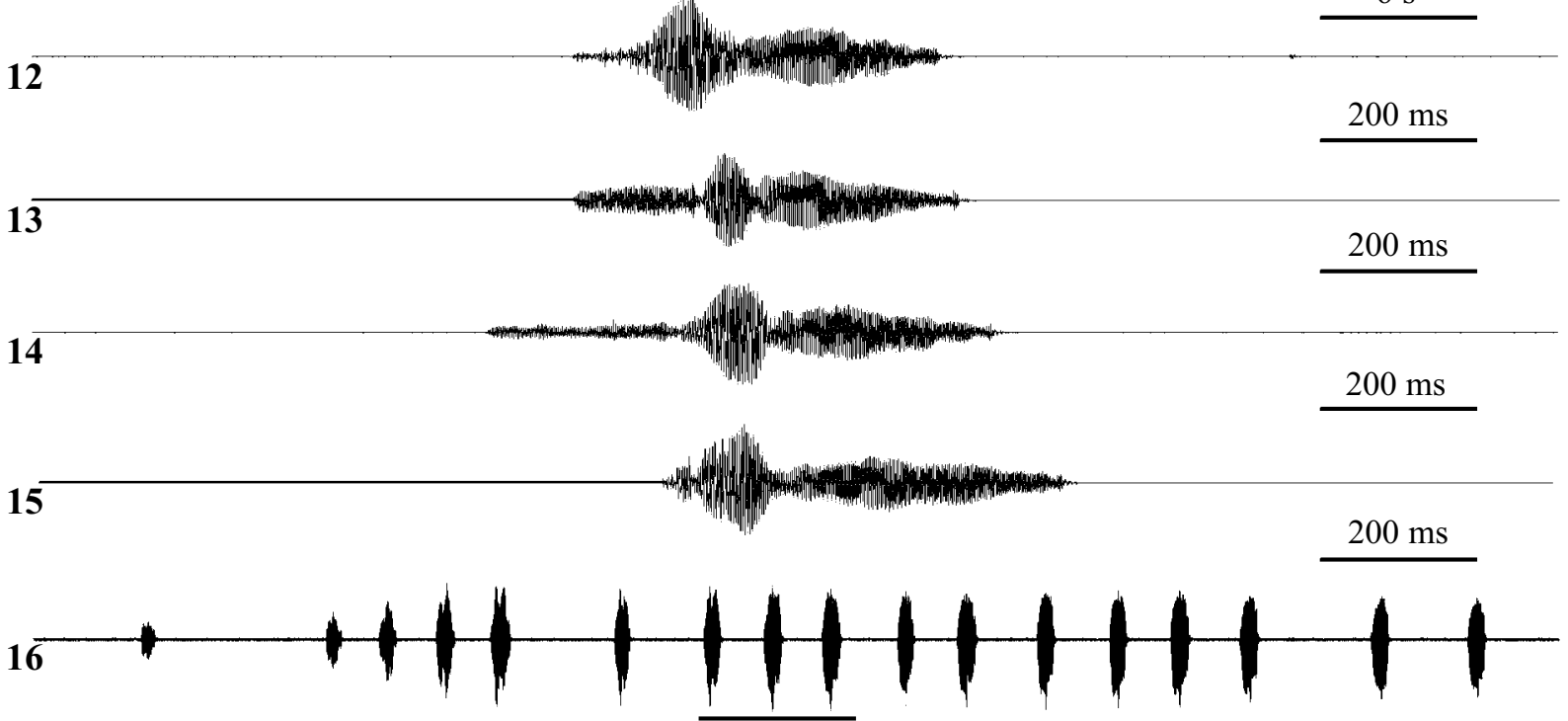
18 2s

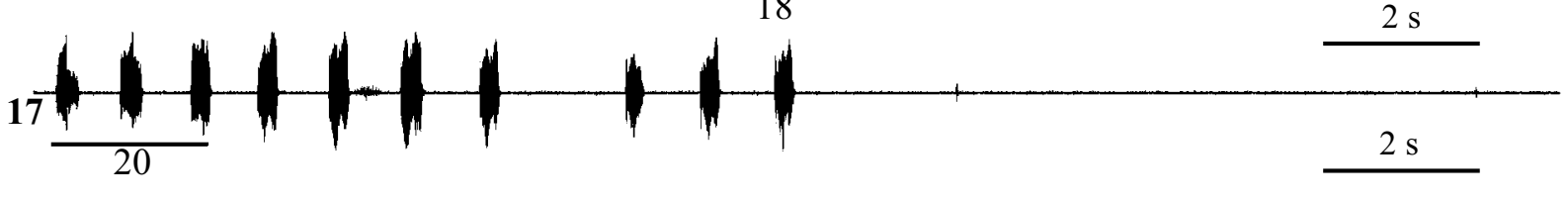

18
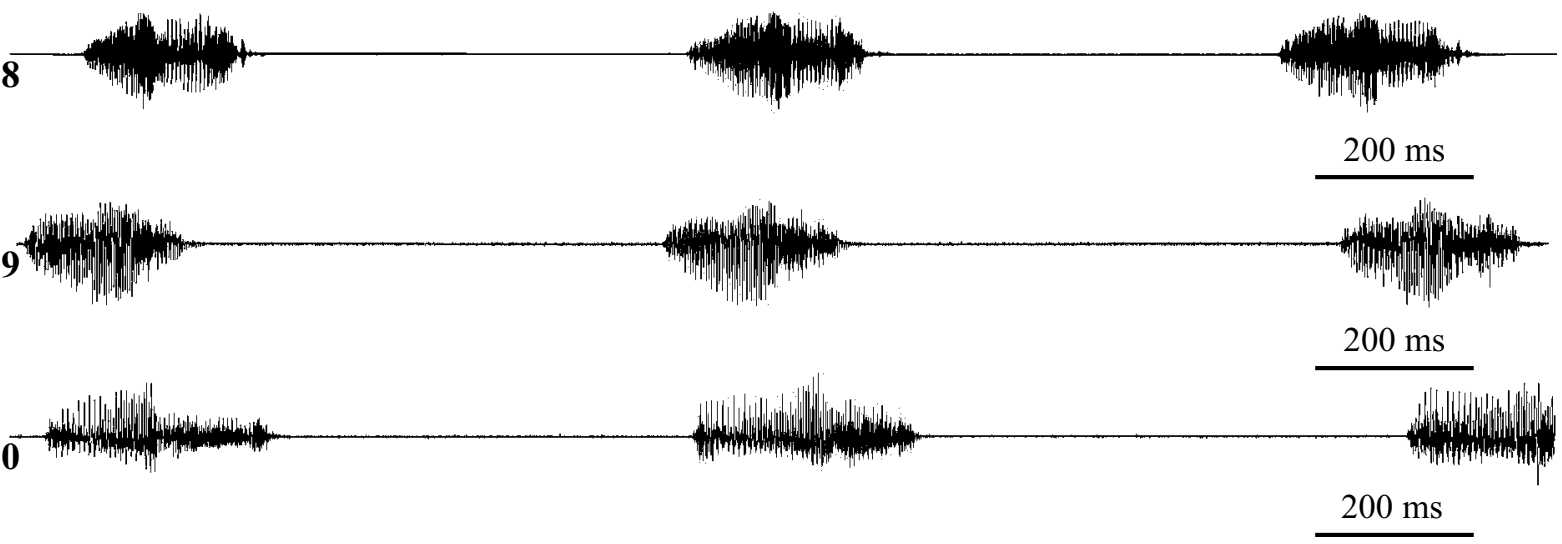

Figs. 11-20. Oscillograms of calling signals of Cicadellidae: 11-15 - Drabescus vilbastei, single male; 16-20 - Platymetopius koreanus; 16 and 18-19 - the male from Buryatia; 17 and 20 - the male from Maritime Province. Faster oscillograms of the parts of signals indicated as "12-15", "18" and " 20 " are given under the same numbers.

Рис. 11-20. Осциллограммы призывных сигналов Cicadellidae: 11-15 - Drabescus vilbastei, одиночный самец; 16-20 Platymetopius koreanus; 16 и 18-19 - самец из Бурятии; 18 и 20 - самец из Приморья. Фрагменты сигналов, помеченные цифрами “12-15”, “17” и “20”, представлены при большей скорости развёртки на осциллограммах под соответствующими номерами. 
As can be seen from the examples cited above, intraspecific variability of the calling signal pattern in leafhoppers is far greater than in other insects. Even the changes of the phrase duration and of syllable repetition period can result in considerable differences between the signals of the same species.

Amplitude distortions during transmission of the waves via the substrate also affect the shape of the
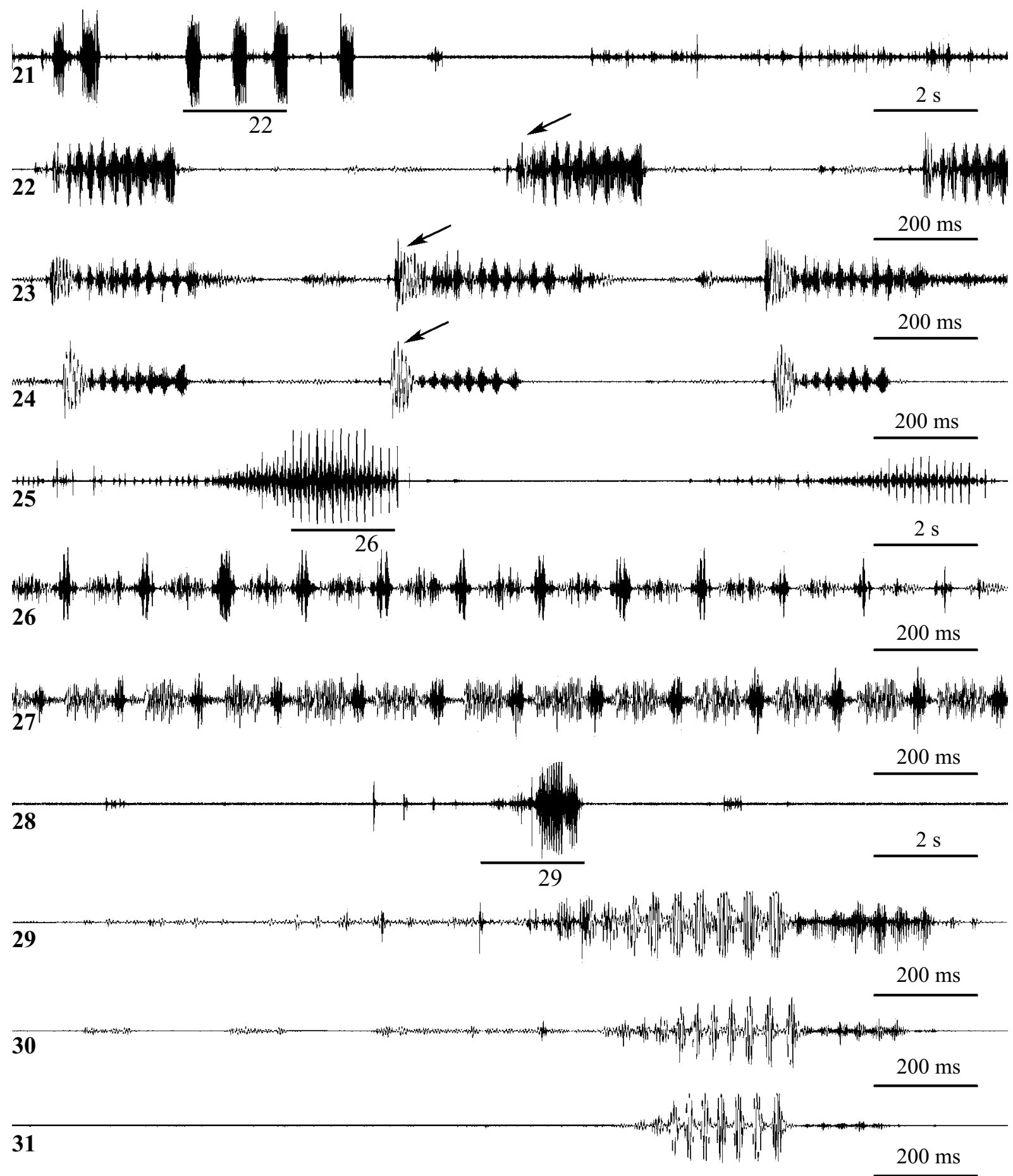

Figs. 21-31. Oscillograms of calling signals of Cicadellidae: 21-24 — Cicadula frontalis mesasiatica; 25-27 - Iassus lateralis; 2831 - Rhytidodus tenebricans Dub. Faster oscillograms of the parts of signals indicated as " 22 ", " 26 " and " 29 " are given under the same numbers.

Рис. 21-31. Осциллограммы призывных сигналов Cicadellidae: 21-24 — Cicadula frontalis mesasiatica; 25-27 - Iassus lateralis; 28-31 - Rhytidodus tenebricans. Фрагменты сигналов, помеченные цифрами “22”, “26” и “29”, представлены при большей скорости развёртки на осциллограммах под соответствующими номерами. 


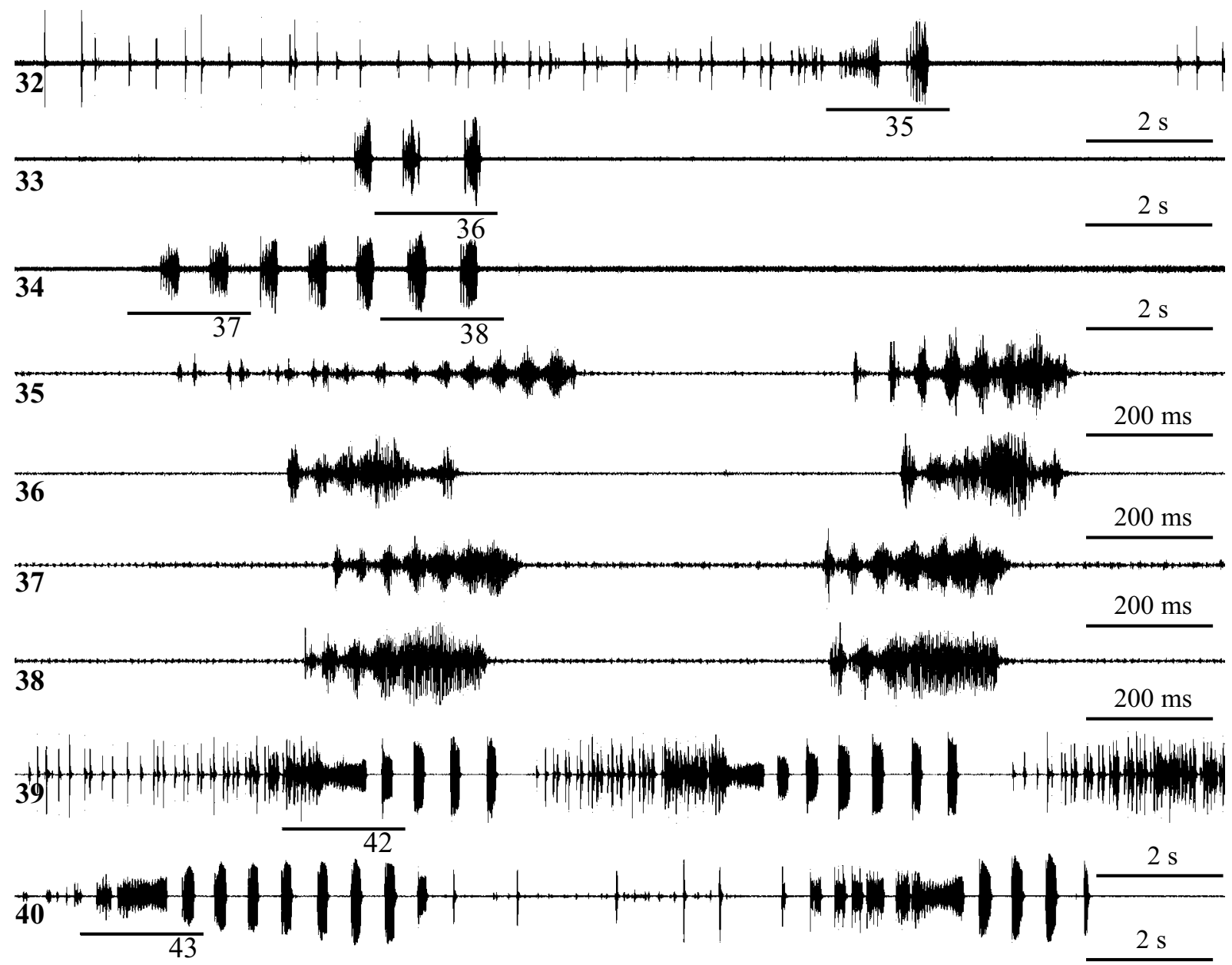

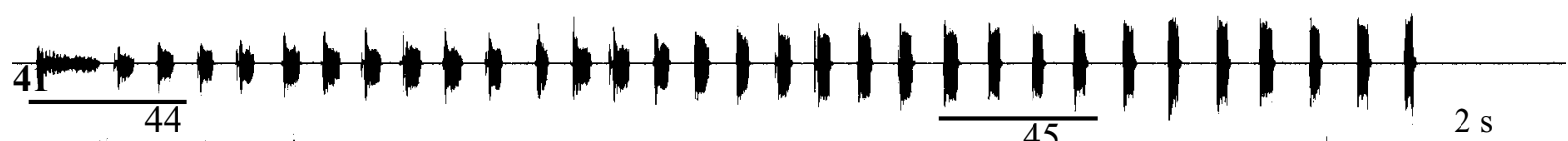
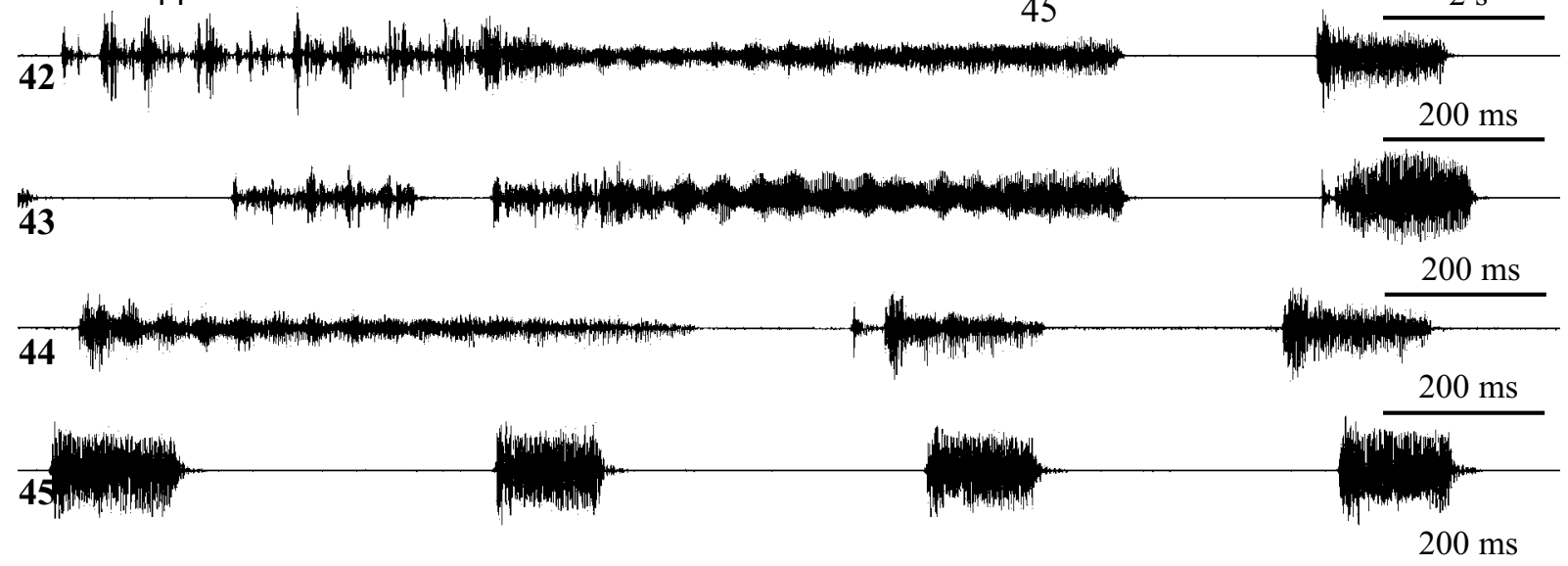

Figs. 32-45. Oscillograms of calling signals of Cicadellidae: 32-38 - Dorycephalus baeri; 39-45 - D. hunnorum. Faster oscillograms of the parts of signals indicated as " $35-38$ " and " $42-45$ " are given under the same numbers.

Рис. 32-45. Осциллограммы призывных сигналов Cicadellidae: 32-38 - Dorycephalus baeri; 39-45 - D. hunnorum. Фрагменты сигналов, помеченные цифрами “35-38” и “42-45”, представлены при большей скорости развёртки на осциллограммах под соответствующими номерами. 
46

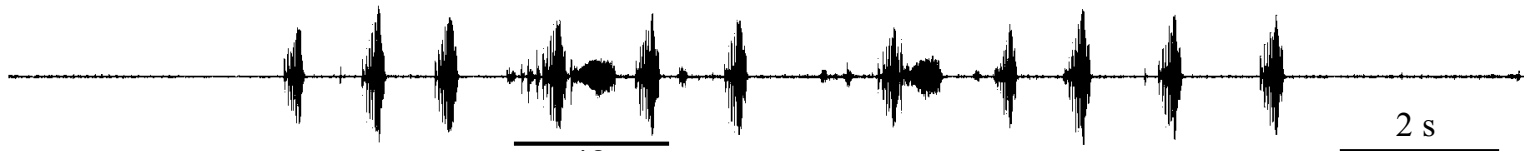

47

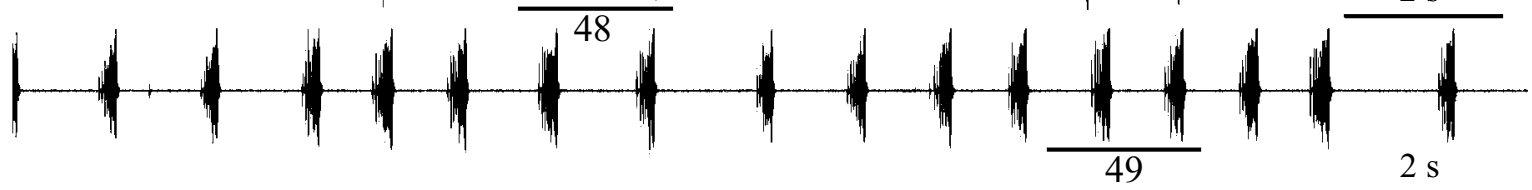

48

s.

49

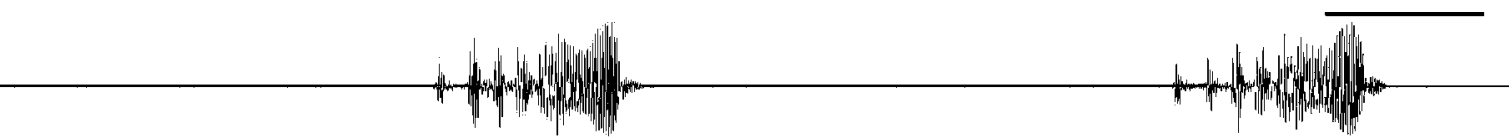

50

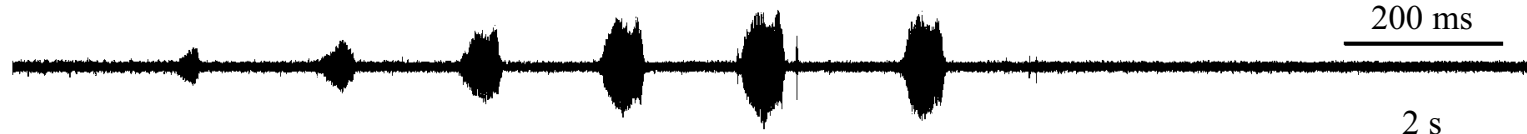

51

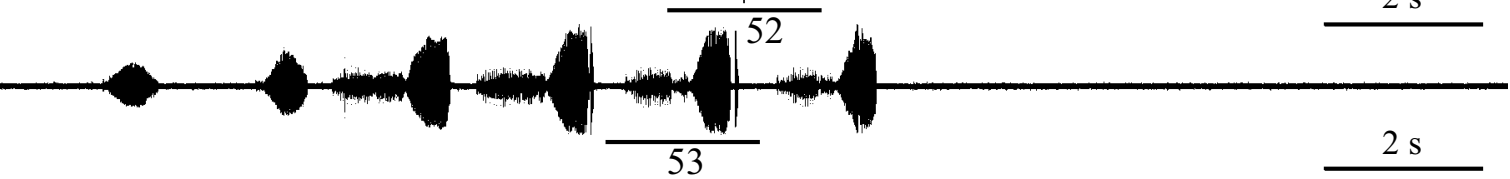

52

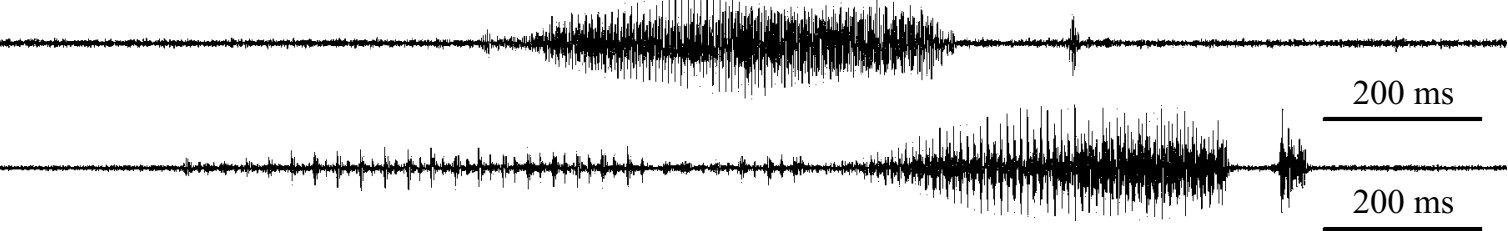

54

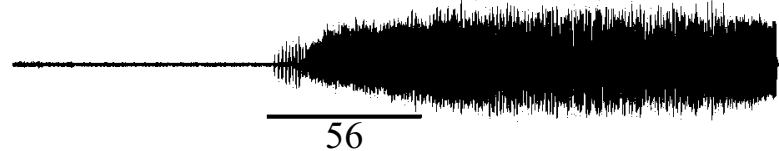

$2 \mathrm{~s}$

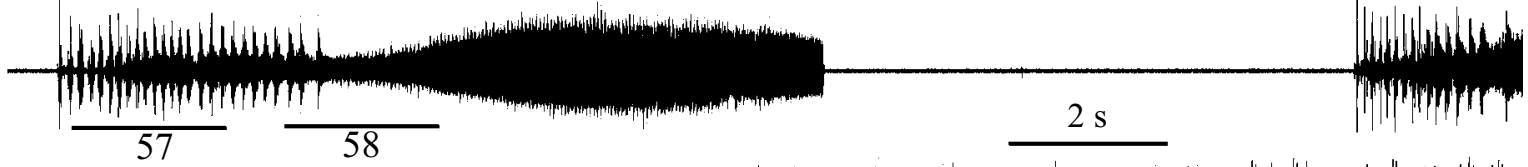

56

+

$200 \mathrm{~ms}$

57

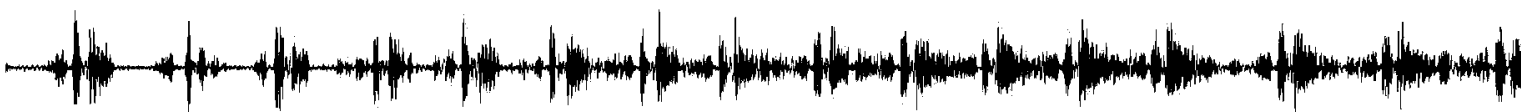

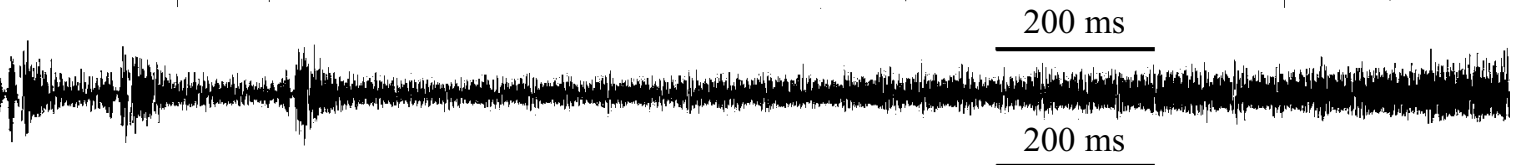

Figs 46-58. Oscillograms of calling signals of Cicadellidae: 46-49 - Orientus ishidae, single male; 50-53 - Allygidius mayri, same; 54-58 - Athysanopsis salicis. Faster oscillograms of the parts of signals indicated as "48-49", "52-53" and "56-58" are given under the same numbers.

Рис. 46-58. Осциллограммы призывных сигналов Cicadellidae: 46-49-Orientus ishidae, одиночный самец; 50-53 - Allygidius mayri, то же; 54-58 - Athysanopsis salicis. Фрагменты сигналов, помеченные цифрами “48-49”, "52-53" и “56-58”, представлены при большей скорости развёртки на осциллограммах под соответствующими номерами. 

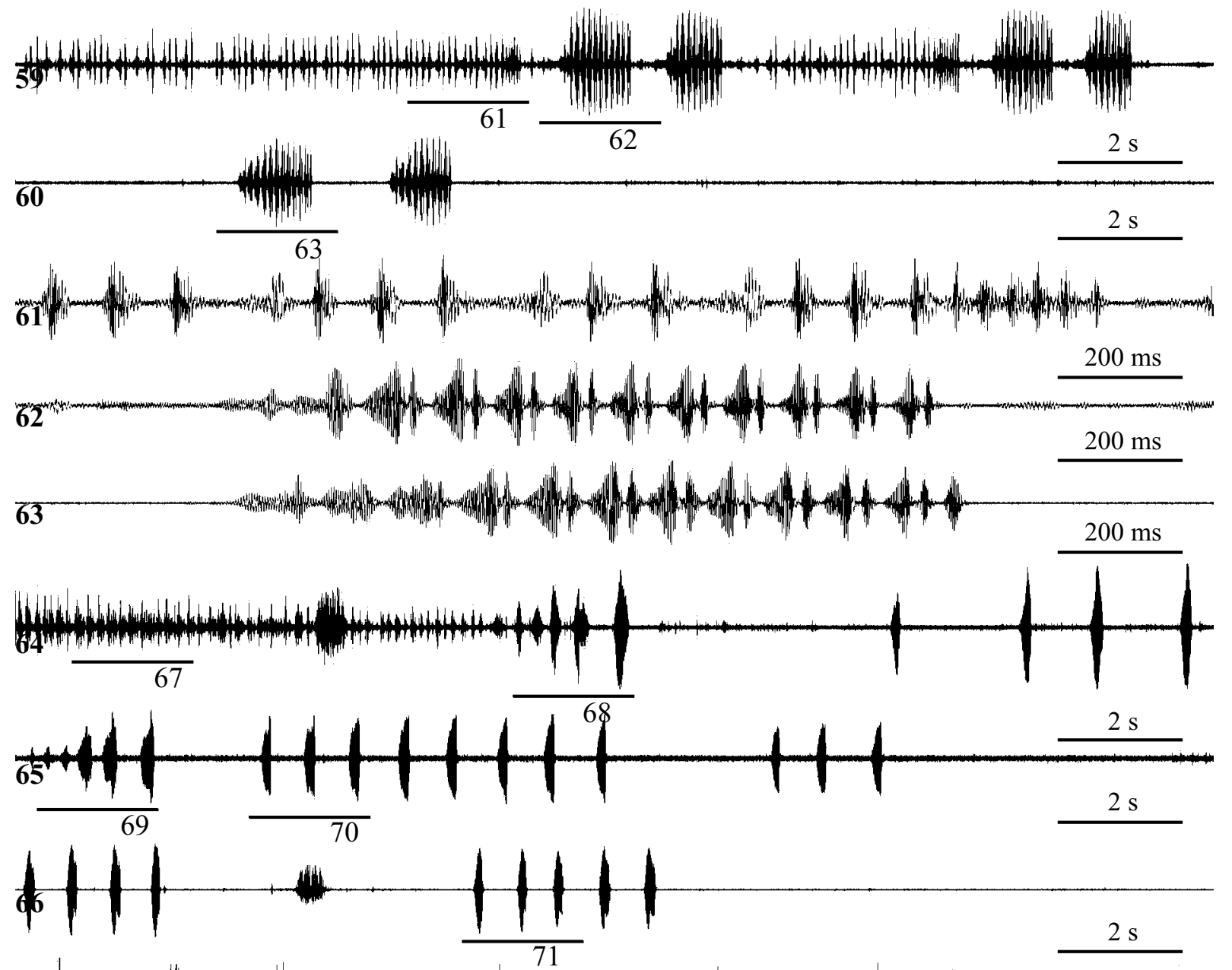

6
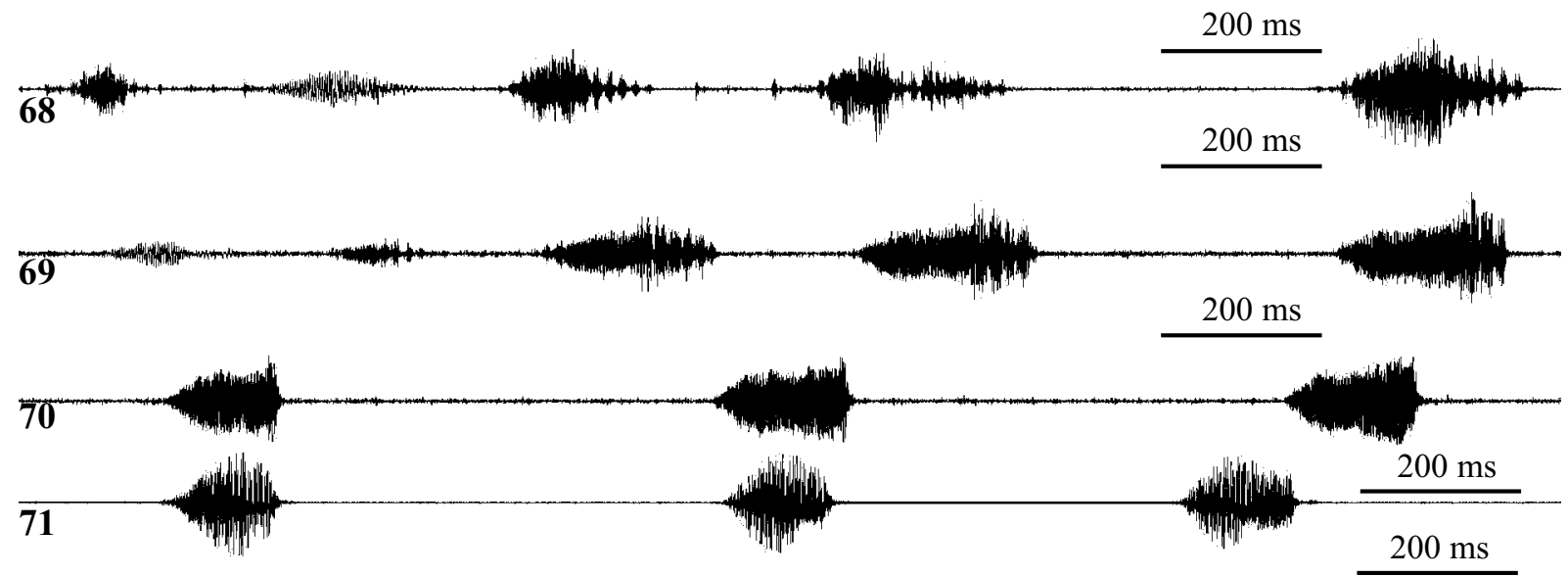

Figs. 59-71. Oscillograms of calling signals of Cicadellidae: 59-63 - Paramesus major; 64-71 - Alobaldia tobae. Faster oscillograms of the parts of signals indicated as "61-63" and "67-71" are given under the same numbers.

Рис. 59-71. Осциллограммы призывных сигналов Cicadellidae: 59-63 - Paramesus major; 64-71 - Alobaldia tobae. Фрагменты сигналов, помеченные цифрами “61-63” и “67-71”, представлены при большей скорости развёртки на осциллограммах под соответствующими номерами. 
signal. Preferential attenuation of certain components of the song occasionally results in considerable change of its appearance on oscillogram.

Since in certain species the calling song occasionally includes facultative parts, the full form of signal differs greatly from the reduced one. Occasionally facultative part has considerably grater duration and much more elaborate temporal pattern than the main one. In this case identification of similar components on the oscillograms looking quite unlike each other sometimes is a difficult task. Nonetheless, even the extreme variants of the signal necessarily include identical components. Therefore, the presence of identical components even in the signals differing distinctly from each other suggests their conspecificity. And vice versa, the presence in the song of additional part no matter whether it is short and simple or prolonged and elaborate does not prove that the form under investigation is a good species. This factor should be taken into account in taxonomic studies conducted with use of calling signal analysis.

In certain cases the variability of signal structure is so great that only investigation of signals of a sufficient number of individuals collected in the same biotope or from the same host plant allows to reach the conclusion that the differences observed are the result of a mere intraspecific variability. This is especially true in regard to species producing elaborate signals in which several kinds of variability are combined. Also, it should be particularly emphasized that providing the only oscillogram usually gives but a rough idea of the structure of the song; for this reason in taxonomic works it is desirable, as far as possible, to illustrate the variability of signal pattern.

ACKNOWLEDGEMENTS. I am greatly indebted to Dr. K.A. Kolesnichenko (Botanical Garden of the Moscow State University), A.N. Dubanaev (Sary-Chelekskiy Biosphere Nature Reserve, Kyrgyzstan) and Dr. A.V. Khrustov (Saratov Division of the Institute for Problems of Ecology and Evolution, Russian Academy of Sciences) for their invaluable help during my fieldwork. The study was supported by Russian Foundation for Basic Research (\# 07-04-00349-a) and by a grant of a State Program "Development of Scientific Potential of Higher School" (project "Biological Diversity: Structure, Stability, Evolution").

\section{References}

Claridge M.F. \& Nixon G.A. 1986. Oncopsis flavicollis (L.) associated with tree birches (Betula): a complex of biological species or a host plant utilisation polymorphism // Biol. J. Linn. Soc. Vol.27. P.381-397. den Bieman C.F.M. 1986. Acoustic differentiation and variation in planthoppers of the genus Ribautodelphax (Homoptera, Delphacidae) // Netherlands J. Zool. Vol.36. No.4. P.461-480.

De Vrijer P.W.F. 1984. Variability in calling signals of the planthopper Javesella pellucida (F.) (Homoptera, Delphacidae) in relation to temperature, and consequences for species recognition during distant communication // Netherlands J. Zool. Vol.34. No.3. P.388-406.

Emelyanov A.F. 1999. [Keys to the genera of Deltocephalinae s. 1. (Homoptera, Cicadellidae) of Kazakhstan, central Asia and Mongolia with description of new genera and subgenera] // Entomologicheskoe Obozrenie. Vol.78. No.3. P.589-609 [in Russian with English summary].

Gillham M.C. \& de Vrijer P.W.F. 1995. Patterns of variation in the acoustic calling signals of Chloriona planthoppers (Homoptera: Delphacidae) coexisting on the common reed Phragmites australis // Biol. J. Linnean Society. Vol.54. P.245-269.

Hamilton K.G.A. 1975. Review of the tribal classification of the leafhopper subfamily Aphrodinae (Deltocephalinae of authors) of the Holarctic region (Rhynchota: Homoptera: Cicadellidae) // Can. Entomol. Vol.107. No.5-6. P.477-498.

Ichikawa T. 1976. Mutual communication by substrate vibration in the mating behaviour of planthoppers (Homoptera, Delphacidae) // Appl. Entomol. Zool. Vol.11. No.1. P.8-23.

Ichikawa T., Sakuma M. \& Ishii S. 1975. Substrate vibrations: mating signals of three species of planthoppers which attack the rice plant // Applied Entomol. Zool. Vol.10. No.3. P.162171.

Inoue H. 1982. Species-specific calling sounds as a reproductive isolating mechanism in Nephotettix spp. (Hemiptera, Cicadellidae) // Appl. Entomol. Zool. Vol.17. No.2. P.253-262.

Michelsen A., Fink F., Gogala M. \& Traue D. 1982. Plants as transmission channels for insect vibrational songs // Behavioral Ecology and Sociobiology. Vol.11. P.269-281.

Percy D.M., Boyd E.A. \& Hoddle M.S. 2008. Observations on acoustic signalling in three sharpshooters: Homalodisca vitripennis, Homalodisca liturata, and Graphocephala atropunctata (Hemiptera: Cicadellidae)// Ann. Entomol. Soc. Amer. Vol.101. No.1. P.253-259.

Tishechkin D.Yu. 2000a. Review of the species of the genus Macropsis Lewis, 1834 (Homoptera: Cicadellidae: Macropsinae) from the Russian Far East and adjacent territories of Transbaikalia // Russian Entomol. J. Vol.8 (for 1999). No.2. P. 73-113.

Tishechkin D.Yu. 2000b. Review of the species of the genus Hephathus Ribaut, 1952 (Homoptera: Cicadellidae: Macropsinae) from the territory of Russia with notes on other Palaearctic species of the genus // Russian Entomol. J. Vol.8 (for 1999). No.4. P.239-252.

Tishechkin D.Yu. 2002. Review of the species of the genus Macropsis Lewis, 1834 (Homoptera, Cicadellidae, Macropsinae) from European Russia and adjacent territories // Russian Entomol. J. Vol.11. No.2. P.123-184.

Tishechkin D.Yu. 2009. Calling songs of grasshoppers of the genus Podismopsis (Orthoptera: Acrididae: Gomphocerinae) and potentialities of use of acoustic characters for discrimination between species of the genus // Russian Entomol. J. Vol.17 (for 2008). No.3. P.259-272.

Tishechkin D.Yu. \& Bukhvalova M.A. 2010. Acoustic communication in grasshopper communities (Orthoptera: Acrididae: Gomphocerinae): segregation of acoustic niches // Russian Entomol. J. Vol.18 (for 2009). No.3. P.165-188. 